\title{
Inovasi Media Pembelajaran Sosiologi \\ Melalui Video Pembelajaran Bagi Guru SMA
}

\author{
Nur Endah Januarti \\ Universitas Negeri Yogyakarta, endahjanuarti@uny.ac.id \\ Poerwanti Hadi Pratiwi \\ Universitas Negeri Yogyakarta, ph_pratiwi@uny.ac.id \\ Grendi Hendrastomo \\ Universitas Negeri Yogyakarta, ghendrastomo@uny.ac.id
}

\begin{abstract}
The community service is training for Sociology's teachers in Bantul. This activity is to equip teachers about learning media knowledge and application of instructional media. There are many activities which are conducted to be applied and practiced in sociology classes so that sociology learning becomes interesting and not boring for learners. Training is done through varied lecture methods, discussions, and frequently asked questions. Various lecture methods are used to convey concepts that are important to be understood and mastered by the participants. The material given is the type and characteristics of instructional media. Learning media is devoted to learning videos. Question and discussion methods to provide opportunities for participants to consult in understanding the making of learning media and video learning. Making learning videos using the Windows Movie Maker program. From the training process the teacher is able to produce the learning video of class X, XI, XII. Video learning can be used in learning. Activity is supported by several factors. These factors are First, the existence of adequate experts from the Department of Education Sociology FIS UNY, the two participants are enthusiastic, the three principals who support the activities, and the four fa. The obstacles faced were the different basic abilities of participants and time management participants due to the various tasks of the school that caused their focus not to total training materials.
\end{abstract}

Keywords: Learning innovation, Video learning, Sociology, Senior high school

\section{PENDAHULUAN}

\section{Analisis Situasi}

Perkembangan teknologi

menuntut pembelajaran yang modern. Kegiatan belajar mengajar di sekolah perlu melakukan adaptasi sehingga

Available at

http://journal.unj.ac.id/unj/index.php/jpm menjadi proses yang dapat dinikmati peserta didik. Adanya perubahan dan perkembangan teknologi membuat media pembelajaran menjadi satu hal yang relevan. Guru dapat menarik minat peserta didik dalam proses 
pembelajaran dengan melakukan inovasi pembelajaran. Media pembelajaran menjadi satu sarana yang dapat menarik perhatian peserta didik dan menjadikan proses pembelajaran menjadi menarik dan diminati peserta didik.

Berdasarkan realitas pembelajaran sosiologi di Sekolah Menengah Atas (SMA) seperti telah dikemukakan dirasa perlu untuk melakukan inovasi dalam pengembangan media pembelajaran sebagai suatu kebutuhan bagi peserta didik dan guru di sekolah agar dapat menyukseskan proses pembelajaran. Mengawali proses ini memang perlu dilakukan oleh guru sebagai manajer pembelajaran. Sebagaimana kita tahu guru memiliki tugas dalam merencanakan, melaksanakan dan mengevaluasi pembelajaran (UU No 14 tahun 2005 tentang Guru dan Dosen). Salah satu tugas guru dalam merencanakan pembelajaran adalah membuat sebuah perencanaan pembelajaran yang pada akhirnya dapat menarik minat peserta didik. Terkait hal tersebut maka guru perlu menyiapkan

Available at

berbagai perangkat pembelajaran salah satunya adalah media pembelajaran.

Untuk dapat menciptakan media pembelajaran yang menarik dan kreatif guru perlu melakukan sebuah inovasi. Teknologi yang saat ini hadir di tengahtengah kehidupan peserta didik dapat dimanfaatkan sebagai suatu sarana yang mendukung pembelejaran. Maka melihat peluang ini guru dapat melakukan sebuah inovasi media pembelajaran berbasis teknologi. Efektivitas pembelajaran melalui media visual dapat terlihat dari kenikmatan siswa ketika belajar (membaca) teks yang bergambar atau moving (Haryoko, 2009). Salah satu bentuk media pembelajaran berbasis teknologi yang mendukung pembelajaran seperti itu adalah video pembelajaran.

Hal ini sejalan dengan kondisi dan situasi pembelajaran yang terjadi di Kabupaten Bantul, DIY. Berdasarkan beberapa identifikasi dan analisis di Kabupaten Bantul, DIY ditemukan bahwa ada beberapa tantangan yang kemudian dihadapi guru di sekolah. Guru-guru Sosiologi SMA di Kabupaten Bantul mengalami permasalahan terkait media 
pembelajaran yakni a) Guru-guru Sosiologi pada umumnya masih menggunakan media pembelajaran sederhana, dengan spidol dan whiteboard; b) Guru-guru Sosiologi umumnya belum mengunakan variasi media pembelajaran yang inovatif dan kreatif; c) Proses belajar mengajar kurang menarik dan tidak atraktif yang diakibatkan kurangnya variasi media pembelajaran; d) Guru-guru Sosiologi belum atau kurang memiliki pengetahuan dan kreativitas dalam mengembangkan media pembelajaran. Maka melihat kenyataan tersebut guruguru perlu mendapatkan suplemen untuk meningkatkan kemampuan dalam melakukan inovasi dalam pengembangan media pembelajaran.

\section{Rumusan Masalah}

Berdasarkan analisis situasi di atas maka rumusan masalah dalam kegiatan ini adalah terkait upaya mewujudkan inovasi media pembelajaran guru sosiologi SMA di Kabupaten Bantul melalui pelatihan pembuatan media (video) pembelajaran. Video pembelajaran menjadi pilihan karena berdasarkan kebutuhan yang diinginkan oleh guru.

Available at http://journal.unj.ac.id/unj/index.php/jpm

\section{Tujuan}

Kegiatan bertujuan untuk 1) Memberikan pemahaman dan keterampilan Guru Sosiologi yang SMA tentang inovasi media pembelajaran melalui video pembelajaran; 2) Memberikan pelatihan kepada para guru mata pelajaran sosiologi di SMA terkait produk penelitian yang telah dihasilkan berupa media pembelajaran; 3) Sebagai sarana untuk melakukan diseminasi hasil penelitian; 4) Guru dapat menerapkan dan mempraktekkan di kelas-kelas sosiologi sehingga pembelajaran sosiologi menjadi menarik dan tidak membosankan bagi peserta didik.

\section{Manfaat}

Manfaat yang diperoleh dari kegiatan adalah a) Guru dapat mengikuti perkembangan, maksud, dan tujuan kurikulum dan mampu mengimplementasikannya dalam pembelajaran dan media pembelajaran; b) Guru dapat menyusun, melaksanakan, dan mengembangkan dengan baik media pembelajaran di sekolah; c) Meningkatnya kompetensi guru terutama kompetensi pedagogik dan profesional sesuai Permendiknas 
Nomor 16 Tahun 2007 tentang kualifikasi akademik dan kompetensi guru dan dapat menggunakannya dalam proses pembelajaran.

\section{KAJIAN TEORITIK}

\section{Inovasi Media Pembelajaran}

Sosiologi

Pembelajaran ilmu sosial dalam hal ini sosiologi selama ini dianggap tidak menarik, membosankan dan berat karena proses pembelajaran di kelas terbatas pada ceramah dari guru. Satu cara yang dapat digunakan untuk menyelesaikan masalah tersebut adalah dengan memanfaatkan berbagai media dan alat pembelajaran yang menarik. Media belajar memegang peranan yang penting dalam rangka menciptakan suasana belajar. Karena melalui media motivasi belajar akan meningkat. Media belajar memberi rangsangan kepada peserta didik untuk mempelajari hal hal yang baru, mengaktifkan respon belajar karena dapat memberikan umpan balik hasil belajar dengan segera. Melalui media belajar dapat digalakkan latihanlatihan yang tepat. Media belajar akan menimbulkan kegemaran belajar kepada peserta didik. Proses komunikasi dalam pembelajaran akan menarik jika dilakukan dengan pengalaman langsung. Jika pengalaman langsung tidak dapat dilaksanakan baru kemudian dimediakan, beturut-turut mulai dari tiruan pengalaman (kongkret) sampai penggunaan media berupa lambang digital (abstrak). Pada saat peserta didik harus selalu membaca buku berisi teks cerita tentang fenomena di masyarakat atau melalui artikel berita tentunya akan menimbulkan kebosanan. Keterbatasan dalam melakukan observasi lapangan di masyarakat tentunya juga menjadi penghambat dalam kesuksesan pembelajaran sosiologi. Maka media pembelajaran memang memiliki peran yang penting dalam proses belajar mengajar sosiologi. Dengan media belajar dapat menghemat waktu belajar, memudahkan pemahaman, meningkatkan perhatian peserta didik, meningkatkan aktivitas peserta didik, dan mempertinggi daya ingat peserta didik (Sardiman, 1994). Media belajar sangat membantu dan menarik dalam proses belajar mengajar sosiologi, karena media dapat dipergunakan untuk menghadirkan realitas sosial di masyarakat ke dalam kelas. 


\section{Guru Sosiologi SMA}

Menurut Undang-Undang Republik Indonesia Nomor 14 Tahun 2005 tentang Guru dan Dosen menjelaskan definisi guru adalah pendidik profesional dengan tugas utama mendidik, mengajar, membimbing, mengarahkan, melatih, menilai, dan mengevaluasi peserta didik pada pendidikan anak usia dini jalur pendidikan formal, pendidikan dasar dan pendidikan menengah. Guru Sosiologi di tingkat SMA perlu memiliki kemampuan dalam melaksanakan tugas utama tersebut. Mengingat sosiologi merupakan mata pelajaran dalam ilmu sosial yang selama ini dianggap sebagai ilmu yang abstrak. Di sisi lain ini adalah peluang, karena dalam menjalankan tugas utama tersebut guru justru dapat menjadikan materi dalam sosiologi sebagai sarana untuk menyampaikan pesan dalam pembelajaran. Misalnya materi interaksi sosial, kelompok sosial, konflik sosial, masalah sosial dan lain sebagainya. Melalui materi itu guru dapat mengembangkan strategi dalam melaksanakan tugas mendidik, mengajar, melatih dan membimbing peserta didik.

Bagaimanapun guru memiliki kewenangan dalam mengelola proses pembelajaran sehingga terkait materi, metode dan strategi memang kemudian memerlukan daya kreativitas guru. Berbagai kajian dalam sosiologi dapat dikaitkan dengan tugas dan tanggungjawab guru dalam mengelola proses pembelajaran baik secara individual maupun kelompok. Membahas tentang pemberdayaan komunitas dalam masyarakat yang menjadi materi dalam kelas XII sesuai Kurikulum 2013 (Permendikbud No 24 tahun 2016) tentunya akan menjadi menarik jika dibelajarkan dengan model kelompok dan melalui pengamatan langsung di luar sekolah. Maka salah satu tanggungjawab guru sosiologi adalah menciptakan pembelajaran yang menarik dan sesuai dengan tujuan pembelajaran.

$$
\text { Prinsip Kurikulum } 2013
$$
diantaranya student centered learning, teacher as facilitator, dan pembelajaran ilmiah. Tugas guru dalam karakteristik kurikulum ini adalah sebagai fasilitator yang diharapkan mampu membersamai 
peserta didik dalam menemukan berbagai ilmu pengetahuan yang dipejarinya. Guru tidak bersifat mutlak dalam menguasai proses pembelajaran. Suparlan (2006: 10) memberikan pengertian umum tentang guru yaitu seseorang yang memiliki tugas sebagai fasilitator agar peserta didik dapat belajar atau mengembangkan potensi dasar dan kemampuannya secara optimal melalui lembaga pendidikan sekolah baik yang didirikan oleh pemerintah, masyarakat ataupun swasta. Hal ini sesuai dengan kebutuhan pembelajaran dalam sosiologi. Realitas sosial dalam sosiologi sangat dinamis. Perkembangan masyarakat terjadi secara terus menerus dan berbeda antara satu daerah dengan daerah lain. Tidak mungkin seorang guru akan dapat mengetahui dan menguasai perubahan secara cepat dan menyeluruh. Maka dalam hal ini justru peserta didik diharapkan menemukan dinamika dalam masyarakat yang menjadi obyek kajian dalam sosiologi dan guru sebagai fasilitator bertugas untuk membantu peserta didik dalam memahami dan menganalisa perkembangan tersebut. Oleh sebab itu peran guru sangat berkaitan dengan proses pembelajaran. Menurut Depdiknas (2008: 8) proses pembelajaran merupakan suatu proses yang mengandung serangkaian perbuatan guru dan peserta didik atas hubungan timbal balik yang berlangsung dalam situasi edukatif untuk mencapai tujuan tertentu, dimana dalam proses tersebut terkandung multi peran guru. Peran guru tersebut meliputi banyak hal yaitu guru dapat berperan sebagai pengajar, pemimpin kelas, pembimbing, pengatur lingkungan belajar, perencana pembelajaran, supervisor, motivator dan sebagai evaluator.

Guru adalah pendidik profesional dengan tugas utama mendidik, mengajar, membimbing, mengarahkan, melatih, menilai dan mengevaluasi peserta didik pada pendidikan usia dini jalur pendidikan formal, pendidikan dasar dan pendidikan menengah.

$$
\text { Menjadi guru sosiologi perlu }
$$
memiliki kompetensi dalam melaksanakan tugas dan perannya. Guru sosiologi adalah pendidik yang mampu mentransfer pengetahuan dan nilai-nilai tentang kajian sosiologi kepada peserta 
didik. Maka, peningkatan kompetensi guru sosiologi menjadi keharusan agar guru sosiologi mampu menyesuaikan perkembangan dan tuntutan dalam proses pembelajaran dan kehidupan di masyarakat yang tidak lain juga merupakan obyek kajian sosiologi.

\section{Video Pembelajaran sebagai Media Pembelajaran Sosiologi}

Salah satu contoh strategi yang kemudian digunakan dalam pembelajaran sosiologi dengan menggunakan media pembelajaran adalah proses pembelajaran dengan mengunakan media audio visual. Media audio visual digunakan karena dengan media ini proses pembelajaran tidak lagi mendengarkan, tetap melihat dan merasakan. Menurut konsep Einstein (Wenger, 2004) penglihatan (visual) berisi lebih banyak informasi daripada indera kita yang lain. Kita juga memproses banyak informasi melalui pendengaran. Selain itu diperoleh informasi dari berbagai penelitian terbukti bahwa $80 \%$ dari area otak kita terlibat dalam respon visual, lebih banyak dari indera lainnya. Dari argumentasi tersebut yang mendasari mengapa media audio visual lebih atraktif untuk digunakan dalam proses pembelajaran. Apabila media audio visual digunakan dalam pembelajaran sosiologi juga akan membawa suasana pembelajaran yang lebih menarik. Hal ini karena peserta didik dibawa untuk melihat realitas sosial yang ada di dalam kelas melalui media audio visual yang mampu memperlihatkan fenomena di masyarakat dan dikemas dalam media tersebut.

Media audio visual dapat dibuat mandiri oleh guru, peserta didik atau dapat diakses melalui berbagai teknologi. Contohnya adalah video di youtube. Berbagai macam video pembelajaran yang tersedia di media internet memberikan situasi pembelajaran yang menarik karena fenomena-fenomena aktual dapat dipelajari dengan cepat.

Malcom Fleeming (1988) menyebutkan bahwa dalam rangka penyampaian pesan pendidikan atau pesan instruksional media sangat efektif untuk mengendalikan perhatian. Dalam proses belajar mengajar perhatian memegang peranan penting. Padahal perhatian mempunyai sifat sukar 
terkonsentrasi dalam waktu yang lama. Dengan menggunakan media maka perhatian peserta didik dapat dikendalikan. Bagaimanapun media yang efektif untuk belajar mengajar adalah media yang bersifat interaktif. Peserta didik diberi kesempatan untuk berpartisipasi aktif memberikan respon disaat menggunakan media. Menurut Percival dan Ellington, dalam Budiningsih perhatian yang penuh dalam belajar dengan metode ceramah rentang perhatian makin lama makin menurun drastis. Sementara Bristish Audio Visual Association menyatakan bahwa $75 \%$ pengetaᄀhuan diperoleh melalui indera penglihatan, $13 \%$ melalui indera pendengaran, $6 \%$ indera sentuh dan rabaan, $6 \%$ indera penciuman dan lidah (Budiningsih, 1995). Sardiman, sebagaimana dikutip Budiningsih (1995), menyebutkan bahwa jika proses belajar mengajar hanya mengunakan metode membaca saja, maka pengetahuan yang mengendap hanya $10 \%$ saja, mendengar saja $20 \%$, melihat saja 30 $\%$, melihat dan mendengar bisa mencapai $50 \%$, mengungkapkan sendiri dapat mencapai $80 \%$ dan mengungkap sendiri kemudian mengungkapkan pada kesempatan lain, dapat mencapai $90 \%$. Dengan demikian pengunaan media audio visual menjadi penting dalam proses pembelajaran terutama pembelajaran sosiologi.

\section{MATERI DAN METODE}

Kegiatan pengembangan yang dilaksanakan merupakan kesepakatan dan berdasarkan kebutuhan dari guru Sosiologi di Kabupeten Bantul. Sesuai dengan rancangan kegiatan PPM, kegiatan ini berbentuk pelatihan dan workshop pembuatan video pembelajaran. Khalayak sasaran yang dilibatkan dalam kegiatan PPM ini adalah guru-guru Sosiologi di Sekolah Menengah Atas (SMA) wilayah Bantul DIY, yang tergabung dalam MGMP Sosiologi Kabupaten Bantul. Total seluruh peserta kegiatan adalah 30 guru mata pelajaran Sosiologi SMA. Pemilihan guru Sosiologi di Kabupaten Bantul merupakan bentuk kelanjutan kerjasama yang telah terbentuk sebelum pelaksanaan kegiatan. Dengan kegiatan ini guru dapat menambah pengetahuan terutama berkenaan dengan pengembangan video pembelajaran, 
sehingga pada akhirnya outcome-nya bias menambah wawasan guru dan secara tidak langsung mendorong guru untuk menghasilkan karya ilmiah yang dapat digunakan untuk peningkatan profesionalitas guru. Peserta pelatihan dan workshop pembuatan video pembelajaran ini berjumlah 30 orang guru.

Materi yang diberikan dalam kegiatan ini adalah

1. Urgensi Media dalam Proses Pembelajaran

Merupakan materi utama dalam kegiatan ini. Kegiatan pengabdian diawali dengan pemaparan dan diskusi terkait dengan pentingnya media dalam proses pembelajaran. Media memiliki ragam dan guna yang menjembatani media secara umum dengan video pembelajaran yang akan dibahas kemudian. Materi dalam kegiatan ini dipaparkan melalui proses dialog dan diskusi. Proses ini mendorong guru untuk memaparkan media yang biasa digunakan sekaligus ajang sharing terkait dengan media pembelajaran.

2. Jenis dan karakteristik media pembelajaran.
Materi ini memaparkan tentang berbagai jenis media pembelajaran dan karakteristiknya. Salah satu hal yang ditekankan adalah video pembelajaran yang digunakan di dalam proses pembelajaran. Pada kegiatan ini ditampilkan ragam video pembelajaran yang ada, mulai dari video pembelajaran yang pembuatannya sederhana hingga video pembelajaran yang cukup kompleks/rumit pembuatannya.

Metode pendekatan yang digunakan dalam kegiatan ini adalah:

1. Ceramah dan tanya jawab

Ceramah dilakukan sebagai salah satu bentuk pengenalan tentang kegiatan yang dilakukan pada umumnya, bagaimana kegiatan ini berjalan, dan hal apa yang bisa peserta dapatkan dari kegiatan pengabdian kepada masyarakat ini. Kegiatan yang dilakukan dipadu dengan tanya jawab sebagai salah satu alternatif mendekatkan diri antara pengabdi dengan peserta, sekaligus agar peserta semakin paham tentang apa yang nantinya akan diajarkan.

2. Demonstrasi 
Kegiatan demonstrasi bertujuan untuk memperlihatkan dan memperkenalkan video pembelajaran yang bisa digunakan dalam proses pembelajaran sosiologi, bagaimana membuatnya yang nantinya juga akan dipraktekkan dan merupakan inti dari kegiatan ini.

3. Pelatihan dan Tutorial

Kegiatan ini lebih pada bagaimana macam, jenis dan bentuk video pembelajaran, bagaimana cara menggunakannya, cara pengaplikasikannya pada proses pembelajaran, dan cara membuatnya.

\section{Praktek}

Kegiatan praktek merupakan kegiatan menuangkan hasil tutorial dalam bentuk nyata, yaitu peserta dihadapkan pada praktek langsung. Peserta diajarkan bagaimana membuat video pembelajaran menggunakan program Windows Movie Maker.

\section{Pemecahan Masalah}

Dari berbagai materi dan metode yang dipilih oleh tim pengabdi selanjutnya tim pengabdi merumuskan alur pemecahan masalah yang dijadikan sebagai pedoman dalam kegiatan ini. Pemecahan masalah diawali dari proses penyamaan persepsi tentang pembelajaran dan inovasi terkait media pembelajaran. Setelah itu guru juga melakukan praktek untuk mendapatkan pengalaman langsung terkait pengembangan media pembelajaran yang inovatif. Pada akhirnya guru memiliki produk berupa hasil media pembelajaran yang dikembangkan.

Berdasarkan metode kegiatan yang dipilih dalam pengabdian pada masyarakat ini, maka dalam prakteknya di lapangan langkah-langkah kegiatan pemecahan masalah. Berikut gambaran pemecahan masalah yang dilakukan dalam kegiatan PPM :
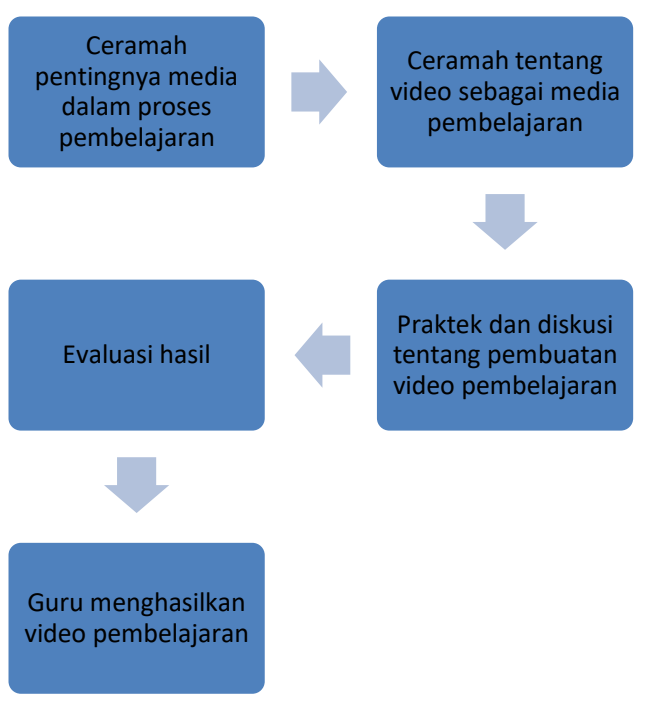

Gambar 1. Alur Pemecahan Masalah 
Berikut penjelasannya :

1. Ceramah tentang pentingnya media dalam proses pembelajaran

Ceramah ini membicarakan tentang pentingnya media dalam proses pembelajaran, macam-macam media yang digunakan, dan keunggulan dan kelemahan media-media tersebut.

2. Ceramah tentang video sebagai media pembelajaran

Ceramah ini membicarakan tentang video sebagai media pembelajaran sosiologi di SMA. Dalam kegiatan ini peserta diberikan contoh beberapa video pembelajaran yang telah dikembangkan dosen dan mahapeserta didik Pendidikan Sosiologi FIS UNY.

3. Praktek dan diskusi tentang pembuatan video pembelajaran

Praktek dan diskusi dilakukan agar guru paham bagaimana membuat video pembelajaran. Masing-masing guru ditugaskan untuk membuat video pembelajaran. Guru diminta membagi materi terlebih dahulu (sesuai dengan Kurikulum 2013) mulai dari kelas X, XI, dan XII. Selanjutnya guru mulai merancang atau membuat video. Materi video bisa berasal dari materi yang telah dikembangkan di kelas masing-masing atau dengan mencari referensi/sumber di media on-line. Video pembelajaran yang telah dibuat oleh para guru selanjutnya dipresentasikan, dengan tujuan agar tim pengabdi dan anggota MGMP lainnya dapat memberikan masukan/saran demi kesempurnaan video tersebut baik dari segi isi (content), maupun tampilan video.

4. Evaluasi hasil

Evaluasi dilakukan untuk mengetahui kekurangan dan kelebihan hasil pelatihan yang telah dilakukan, meliputi cara penyampaian, materi dan keseluruhan proses pelatihan. Dengan evaluasi ini ada follow up dari berbagai kekurangan dan kelebihan pelatihan ini.

\section{HASIL DAN PEMBAHASAN}

Pelatihan Inovasi Media Pembelajaran Sosiologi bagi Guru Sosiologi SMA di Kabupaten Bantul

Kegiatan pengabdian kepada masyarakat ini diselenggarakan berdasarkan hasil riset yang telah dilakukan dan juga terkait dengan kebutuhan guru sosiologi SMA untuk mengembangkan kompetensi pedagogisnya, dalam hal ini untuk pengembangan metode pengajaran 
melalui ragam media pembelajaran. Kegiatan PPM ini diselenggarakan sebagai bagian pengabdian dan kerjasama yang secara kontinyu dilakukan oleh jurusan pendidikan sosiologi UNY yang bermitra dengan sekolah dan guru sosiologi SMA di Daerah Istimewa Yogyakarta.

Kegiatan pengabdian yang dilakukan merupakan rangkaian dari kegiatan kerjasama yang dilakukan pada tahun 2015 yang dimulai dengan Focus Group Discussion di bulan Januari yang membahas terkait program kerjasama dan keinginan untuk mengembangkan MGMP Sosiologi se DIY dan Jateng. Kegiatan terebut kemudian ditindaklanjuti dengan kegiatan workshop secara umum terkait dengan materi pembelajaran dan dilanjutkan dengan kegiatan pengembangan metode pengajaran dan media pembelajaran. Rangkaian kegiatan itulah yang kemudian melahirkan kegiatan pengabdian ini.

Pelatihan Inovasi Media

Pembelajaran Sosiologi menjadi pilihan berdasarkan perkembangan situasi dan kondisi dalam proses pembelajaran sosiologi SMA di Kabupaten Bantul.
Selain itu kebutuhan guru dalam mengembangkan media pembelajaran yang inovatif menjadi satu masalah yang mendukung diselenggarakannya kegiatan pelatihan ini. Maka, tim pengabdi berupaya menyusun kegiatan pelatihan sesuai dengan analisis kebutuhan yang sebelumnya dilakukan. Kegiatan dilaksanakan di sela waktu kegiatan para guru.

Berikut jadwal kegiatan pelatihan yang telah dilaksanakan antara lain:

Tabel 1. Jadwal Pelaksanaan Kegiatan PPM

\begin{tabular}{rll}
\hline No & Kegiatan & Waktu \\
\hline 1. & Seminar instrumen & Awal April \\
& pengabdian & \\
2. & Koordinasi dengan pihak & Akhir \\
& MGMP & April \\
3. & Rencana penentuan & Mei \\
& kegiatan awal PPM & \\
4. & Koordinasi lanjutan & Juni \\
& terkait pelaksanaan PPM & \\
5. & Pencairan dana kegiatan & Awal Juli \\
6. & Koordinasi lanjutan & Agustus \\
& terkait teknis & \\
& pelaksanaan PPM & \\
7. & Penentuan jadwal & Agustus \\
8. & Pegiatan PPM & \\
9. & Evaksanaan Kegiatan & Agustus - \\
\hline 10 & Penyusunan Laporan & Oktober \\
\hline & & September \\
& \\
&
\end{tabular}




$\overline{\mathrm{PPM}}$

Jumlah peserta yang mengikuti kegiatan ini adalah 30 orang peserta. Peserta yang mengikuti kegiatan ini semuanya merupakan guru Sosiologi yang tergabung dalam MGMP Sosiologi Kabupaten Bantul, baik guru yang sudah berstatus PNS (Pegawai Negeri Sipil) maupun guru yang masih berstatus kontrak. Guru-guru tersebut berasal dari SMA (Sekolah Menengah Atas) maupun MA (Madrasah Aliyah). Pelaksanaan pelatihan dan workshop media (video) pembelajaran dilaksanakan dalam 5 (lima) pertemuan, dengan rincian sebagai berikut:

Tabel 2. Jadwal Kegiatan Pelatihan Pembuatan Media Pembelajaran bagi Guru Sosiologi SMA di Kabupaten Bantul - DIY

\begin{tabular}{clll}
\hline No. & $\begin{array}{l}\text { Hari, } \\
\text { Tanggal }\end{array}$ & Materi & Tempat \\
\hline 1. & Rabu, 10 & Jenis dan & SMAN 3 \\
& Agustus & Karakteristik & Bantul \\
& 2016 & Video & \\
& & Pembelajaran & \\
2. & Rabu, 24 & Praktek & Laborato \\
& Agustus & Pembuatan & rium \\
& 2016 & Video & Kompute \\
& & Pembelajaran & r FIS \\
& & & UNY \\
& & & (FISNET \\
\cline { 3 - 4 } & & &
\end{tabular}

\begin{tabular}{llll}
\hline & & & - \\
& & & $\begin{array}{l}\text { Gedung } \\
\text { Kuliah } \\
\text { Utara })\end{array}$ \\
& & & MAN \\
3. & Rabu, 31 & Penugasan dan & Gandeka \\
& Agustus & Bimbingan & n Bantul \\
& 2016 & Mandiri & SMAN 1 \\
4. & Rabu, 7 & Penugasan dan & Sewon \\
& Septemb & Bimbingan & \\
& er & Mandiri & \\
& 2016 & & SMAN 1 \\
\hline 5. & Rabu, 14 & Presentasi & \\
& Septemb & Video & Bantul \\
& er & Pembelajaran & \\
2016 & & \\
\hline
\end{tabular}

Deskripsi kegiatan pengabdian yang telah dilakukan oleh tim pengabdi dapat dijelaskan sebagai berikut:

1. Pada hari pertama (Rabu, 10 Agustus 2016) materi kegiatan yang diberikan adalah urgensi media dalam proses pembelajaran, serta jenis dan karakteristik video pembelajaran. Pada tahapan ini juga didiskusikan beberapa hal terkait bagaimana teknis pembuatan video pembelajaran, materi/topik dari video yang akan dibuat oleh guruguru MGMP Sosiologi Kabupaten Bantul.

2. Selanjutnya pada hari kedua (Rabu, 24 Agustus 2016) materi kegiatan

Available at

http://journal.unj.ac.id/unj/index.php/jpm 
yang diberikan adalah praktek pembuatan video pembelajaran. Untuk membuat video pembelajaran, peserta menggunakan bantuan program Windows Movie Maker. Kegiatan ini dilaksanakan di Laboratorium Komputer FIS UNY. Dalam membuat rancangan video pembelajaran, peserta dipandu secara tutorial oleh tim pengabdi dan didampingi oleh beberapa mahapeserta didik Prodi Pendidikan Sosiologi FIS UNY.

3. Hari ketiga (Rabu, 31 Agustus 2016) dan hari keempat (Rabu, 7 September 2016), peserta melanjutkan pembuatan video pembelajaran secara mandiri. Beberapa peserta yang sudah menyelesaikan pembuatan video pembelajaran dapat membantu rekan sejawatnya (jika diperlukan).

4. Hari kelima (Rabu, 14 September 2016) peserta mempresentasikan hasil video pembelajaran yang telah dibuat. Setelah perserta mempresentasikan hasil, dilanjutkan dengan sesi diskusi. Sesi diskusi ditujukan agar tim pengabdi dan peserta (guru) yang lain dapat memberikan masukan/saran terkait video yang telah dibuat.

Dari proses pelatihan guru mampu menghasilkan video pembelajaran sosiologi kelas X, XI, XII yang dapat digunakan dalam pembelajaran. Guru juga dapat mengunggah video karya mereka di internet sehingga dapat diakses oleh peserta didik.

\section{Faktor Pendukung dan Penghambat}

Pelaksanaan kegiatan PPM ini secara umum sesuai dengan target tim pengabdi, mulai dari jumlah peserta, hasil yang diharapkan, dan evaluasi yang berjalan dengan lancar, walaupun ada berbagai hambatan namun kegiatan ini dapat diselenggarakan dengan baik.

Pelaksanaan pengabdian pada masyarakat ini muncul dengan berbagai macam hal yang menarik yang bisa dijadikan sebagai pelajaran dan pengalaman ke depan dalam memberikan materi pelatihan. Berbagai macam permasalahan dan solusi muncul ketika program ini dilaksanakan, mulai dari hal-hal yang relatif standar maupun hal-hal yang tidak terduga yang justru selain menambah wawasan bagi peserta juga menambah wawasan pengabdi, 
sehingga pengabdi pun mendapatkan sesuatu yang berharga yang digunakan sebagai tambahan pengetahuan untuk melaksanakan pengabdian pada masyarakat di waktu yang akan datang.

Berikut ini disampaikan beberapa faktor pendukung dan penghambat selama berjalannya program pengabdian ini.

\section{Faktor Pendukung}

a. Koordinasi dan kerjasama tim pengabdi yang sangat baik sehingga program pengabdian ini bisa berjalan dengan lancar.

b. Peran serta yang aktif dari pihak guru-guru Sosiologi MGMP Kabupaten Bantul yang secara aktif mencoba untuk berpartisipasi dan memberikan banyak bantuan demi kelancaran program pengabdian ini. Bahkan sebelum pelaksanaan dilakukan.

c. Bantuan dari pihak sekolah sebagai tempat penyelenggaraan kegiatan PPM dan MGMP Sosiologi Kabupaten Bantul.

d. Antusiasme peserta yang begitu luar biasa, diluar dugaan tim pengabdi sehingga materi yang kami sampaikan menjadi lebih cepat diterima.

e. Munculnya berbagai macam pertanyaan yang memudahkan tim pengabdi mencari alternatif materi pelatihan, sehingga apa yang diajarkan pada peserta dapat diterima secara efektif

f. Adanya jadwal tetap guru-guru berkumpul setiap minggunya, sehingga memudahkan koordinasi.

g. Keseriusan peserta dalam mengikuti semua materi pelatihan sekaligus melakukan praktek untuk membuat video pembelajaran.

h. Kesukarelaan guru untuk melaksanakan praktek pembuatan video pembelajaran sebagai bagian kegiatan pengembangan diri

2. Faktor Penghambat

a. Kemampuan dasar yang berbedabeda dari para peserta yang menyulitkan pengabdi dalam menyesuaikan materi pelatihan. Ada peserta yang sudah relatif tahu dan mengenal video pembelajaran, ada yang sama sekali belum mengenal dan 
kemungkinan tidak familier dalam penggunaan video pembelajaran, misalnya masih canggung dalam menggunakan video pembelajaran.

b. Kesibukan peserta yang akhirakhir ini disibukkan dengan berbagai macam tugas dari pihak sekolah yang menyebabkan fokus mereka tidak total ke materi pelatihan.

c. Tidak semua komputer (desktop, laptop, notebook) guru memiliki program Windows Movie Maker, sehingga harus meng-install terlebih dahulu sehingga tidak bisa melanjutkan untuk membuat video pembelajaran saat di rumah.

Pelaksanaan kegiatan PPM ini secara umum sesuai dengan target tim pengabdi, mulai dari jumlah peserta, hasil yang diharapkan, dan evaluasi yang berjalan dengan lancar, walaupun ada berbagai hambatan mulai dari mencari waktu yang tepat sampai masalah pencarian tempat, akhirnya semua bisa dipecahkan dengan kerjasama semua pihak yang mendukung terselenggaranya kegiatan ini.
Pelaksanaan

kegiatan pengabdian pada masyarakat yang telah dilaksanakan oleh tim pengabdi mendapatkan respon yang positif dari peserta. Sejak pertama kali program ini dibicarakan dengan perkumpulan MGMP Sosiologi Kabupaten Bantul, antusiasme sangat terasa, bahkan munculnya kegiatan ini justru didorong dari kebutuhan guru untuk menambah dan mengembangkan materi tentang media pembelajaran. Atas dasar kebutuhan guru-guru itulah kemudian tim pengabdi mulai melakukan koordinasi dengan Pengurus MGMP Sosiologi Kabupaten Bantul.

\section{Inovasi Media Pembelajaran}

\section{Sosiologi melalui Video Pembelajaran}

Media pembelajaran yang dikembangkan merupakan bagian dari pengembangan media pembelajaran yang digunakan untuk meningkatkan kualitas pembelajaran pada mata pelajaran sosiologi di SMA. Berdasarkan hasil penelitian yang dilakukan sebelumnya menunjukkan bahwa penggunaan media pembelajaran dalam pembelajaran sosiologi di SMA menunjukkan hasil yang memuaskan. Media pembelajaran mampu 
mendorong daya kreativitas dan imajinasi peserta didik untuk memahami materi yang diajarkan. Dari sisi guru, media pembelajaran mendorong variasi dalam proses pembelajaran. Melalui media pembelajaran, guru dituntut untuk memberikan pemahaman dengan cara yang berbeda yang mendorong daya pikir peserta didik untuk menangkap konsep materi yang diajarkan.

Berdasarkan hasil dari penelitian tersebut, dilakukan penjajagan ke beberapa sekolah melalui MGMP mata pelajaran sosiologi untuk melakukan penyebarluasan informasi terkait dengan pengembangan media pembelajaran. Respon awal dari guru sosiologi SMA menunjukkan tingginya minat guru untuk mengetahui cara pengembangan media pembelajaran agar dapat digunakan dalam proses pembelajaran. Dari respon tersebut mendorong penelitian pengembangan media pembelajaran untuk disosialisasikan ke guru melalui MGMP, salah satunya di MGMP mata pelajaran sosiologi Kabupaten Bantul.

Penjajagan awal untuk pelaksanaan kegiatan dimulai dengan melakukan persiapan terkait dengan model kegiatan yang akan dilakukan. Beberapa proses diskusi dilakukan antara tim pengabdi dengan perwakilan MGMP sosiologi Kabupaten Bantul yang pada akhirnya membuat rencana proses kegiatan yang dilakukan.

Video pembelajaran menjadi pilihan dalam inovasi media pembelajaran yang dilakukan dalam kegiatan karena beberapa pertimbangan yakni sumber daya guru, sarana sekolah, dan obyek kajian sosiologi yang sesuai dengan model pengembangan video pembelajaran. Selain itu video pembelajaran saat ini sangat dekat dengan peserta didik. terbukti dengan berkembangnya berbagai macam bentuk video seperti video blog.

$\begin{array}{rrr} & \text { Video pembelajaran adalah } \\ \text { media } & \text { pembelajaran yang }\end{array}$
dikembangkan oleh guru dalam proses inovasi pembelajaran sosiologi. Video pembelajaran memuat gambar, suara dan aktivitas yang dapat dilihat dan didengar untuk memahami suatu fenomena atau kejadian di masyarakat. Video pembelajaran dapat diunggah dan diakses dengan memanfaatkan 
perkembangan teknologi yang sedang berkembang. Keberadaan internet dapat diintegrasikan dengan video pembelajaran sebagai salah satu bentuk inovasi pembelajaran yang digunakan oleh guru sebagai bentuk penyesuaian dalam perkembangan lingkungan eksternal pendidikan. Video pembelajaran dapat diunggah dan diakses peserta didik secara mandiri. sebagai contoh melalui youtube sebagai salah satu sarana di media internet juga sudah banyak diakses oleh peserta didik.

Melalui video pembelajaran menjadi cara untuk membangun pola pembelajaran interaktif antara peserta didik, guru dan media pembelajaran. Proses pelibatan ini misalnya pada saat berada di dalam kelas guru melibatkan media pembelajaran berupa video pembelajaran tersebut pada saat proses pembelajaran. Video pembelajaran berfungsi sebagai bahan atau sumber belajar. Selain itu peserta didik mampu mengakses sumber belajar berupa video tersebut melalui internet. Pada proses lainnya ketika guru membuat video pembelajaran yang digunakan dalam proses pembelajaran mampu dimaknai sebagai suatu bentuk strategi atau metode pembelajaran. Hal ini sangat sesuai dengan karaktersitik Kurikulum 2013. Terdapat proses ilmiah tatkala peserta didik mendapatkan tugas berbasis proyek untuk pembuatan video pembelajaran tentang realitas sosial atau fenomena di lingkungannya. Inilah bentuk implementasi dari model pembelajaran project based learning dalam Kurikulum 2013. Pada saat peserta didik membuat video pembelejaran terdapat proses pengamatan, menanya, menelaah, menganalisis, menyusun dan akhirnya mempresentasikan pekerjaan yang mereka buat dalam video pembelajaran. Apalagi jika dilakukan dalam bentuk kelompok. Terjadi proses diskusi, analisis dan manajemen kelompok yang sangat mendukung upaya pembelajaran student centered learning. Tugas guru sebagai fasilitator yang mendampingi peserta didik dalam mengembangkan kemampuannya baik secara kognitif, afektif, dan psikomotorik.

\section{KESIMPULAN DAN SARAN \\ Peningkatan Kapasitas Guru Sosiologi SMA melalui Pelatihan}


Pembuatan Video Pembelajaran Bagi Guru Sosiologi SMA di Kabupaten Bantul, Daerah Istimewa Yogyakarta yang dilaksanakan dalam rangka pengabdian pada masyarakat ini memperoleh antusiasme yang besar dari peserta, mulai dari metode yang dilaksanakan sekaligus juga dari materi yang diberikan memberikan wawasan yang baru bagi peserta.

\section{Pembelajaran Sosiologi di} Sekolah Menengah Atas (SMA), yang pada umumnya dirasa membosankan dan disepelekan oleh sebagian besar peserta didik, adanya anggapan bahwa Sosiologi hanyalah menjelaskan tentang materi yang sudah, dan kebanyakan guru-guru yang mengajar Sosiologi masih monoton dalam menyampaikan materi sehingga tidak mampu menyampaikan materi dengan dinamis dan atraktif, pada akhirnya bisa dipecahkan dengan pembuatan video pembelajaran yang selanjutnya dapat digunakan pada proses pembelajaran sosiologi di kelas.

Kemampuan peserta (guru) dalam menyerap apa yang diajarkan memberikan optimisme bahwa nantinya mereka mampu membuat media (video) pembelajaran yang lebih baik, lebih menarik dan atraktif yang pada akhirnya akan memberikan pemahaman yang lebih mendalam bagi peserta didik. Secara keseluruhan kegiatan pelatihan pembuatan video pembelajaran ini dapat dikatakan berhasil. Keberhasilan ini diukur dari empat komponen, yaitu: Keberhasilan target jumlah peserta pelatihan, Ketercapaian tujuan pelatihan, Ketercapaian target materi yang telah direncanakan, dan Kemampuan peserta dalam penguasaan materi. Pada akhirnya pelatihan ini bisa berjalan dengan lancar dan memberikan tambahan ilmu dan wawasan yang berharga baik bagi peserta maupun bagi tim pengabdi.

Selanjutnya beberapa hal yang dapat direkomendasikan untuk proses berikutnya sebagai beriku. Pengembangan mutlak diperlukan untuk mendapatkan hasil yang lebih baik lagi, dalam artian peserta setelah pelatihan ini selesai tidak serta merta belajarnya juga selesai, tetapi peserta bisa mengembangkan lagi dengan belajar mandiri untuk mengembangkan apa yang telah didapatkan dalam pelatihan ini. Pihak sekolah perlu 
memfasilitasi dan mendorong pengembangan media pembelajaran khususnya video pembelajaran bagi para guru sehingga profesionalitas dan kualitas pembelajaran semakin meningkat.

Dalam penggunaan media
pembelajaran
guru

\section{DAFTAR PUSTAKA}

Budiningsih, C. Asri. (1995). Strategi Menggunakan Media Pengajaran bagi Pendidikan Dasar. Jurnal Cakrawala Pendidikan Edisi 1 Tahun XIX, Tahun 1995, Hal 6576

Danim, Sudarwan. (2002). Inovasi Pendidikan dalam Upaya Peningkatan Profesionalisme Tenaga Kependidikan. Jakarta: Pustaka Setia.

Fleming, Malcom dan W Howard Levie. (1988). Instructional Masage Design. New Jersey: Educational Technology Publications.

Haryoko, Sapto. (2009). Efektivitas Media Audio Visual sebagai Alternatif Optimalisasi Model Pembelajaran. Jurnal Edukasi@Elektro Vol. 5 No 1, Maret 2009 hal. 1-10.
Mediawati, Elis. (2011). Pembelajaran Akuntansi Keuangan Melalui Media Komik Untuk Meningkatkan Prestasi Mahapeserta didik. Jurnal Penelitian Pendidikan Vol. 12 No. 1, April 2011 hal 68-76.

Novianti \& Syaichudin. (2010). Pengembangan Media Komik Pembelajaran Matematika untuk meningkatkan Pemahaman bentuk Soal Cerita Bab Pecahan Pada Peserta didik Kelas V SDN Ngembung. Jurnal Teknologi Pendidikan Vol 10 No 1, April 2010 Hal 74-85.

Peraturan Menteri Pendidikan dan Kebudayaan No 24 tahun 2016 tentang Kompetensi Inti dan Kompetensi Dasar Kurikulum 2013.

Wahyuningsih, Ari Nur. (2011). Pengembangan Media Komik Bergambar Materi Sistem Saraf Untuk Pembelajaran Yang Menggunakan Strategi PQ4R. Jurnal Penelitian Pendidikan. Volume 1, No. 2, Desember 2011. Hal 102-110.

Wenger, Win. (2004). Beyond Teaching \& Learning. Bandung: Nuansa.

Available at

http://journal.unj.ac.id/unj/index.php/jpm 